Images in...

\title{
Mystery of a giant leg
}

\author{
M R Siddiqui, O T Islam, A Hossain \\ Department of Medicine, Dhaka Medical College Hospital, Dhaka, Bangladesh
}

Correspondence to M R Siddiqui, dr.mahmud99@yahoo.com

\section{DESCRIPTION}

A 20-year-old man presented with gradual enlargement and disability of the left lower limb since birth. At birth his parents noticed that his left lower limb was a bit bigger than his right, and since then it gradually enlarged in length and breadth, with a distorted shape. His left leg became so big that he could not use it for the last 10 years and became bed bound. Clinical examination revealed a port wine stain on his left lower abdominal wall and part of the left lower limb. His left lower limb was hugely enlarged from his left buttock to the toes. The skin over that limb was hyperpigmented, dry and scaly without any skin ulceration or engorged vessels. His left leg resembled an elephant's leg, with a length of 5 feet 1 inches (approximately $155 \mathrm{~cm}$ ) and maximum diameter of 47 inches (approximately $119 \mathrm{~cm}$; figure 1). His right leg was normal. An x-ray of the left limb showed all the bones and soft tissue shadow were grossly enlarged. The head of the femur was dislocated from the hip joint and all the tarsal and metatarsal bones were widely displaced from each other. With all the above features, he was diagnosed as having Klippel-Trenaunay-Weber syndrome. To the best of our knowledge, there is no previous report on Klippel-Trenaunay-Weber syndrome with such an enlarged limb.

Klippel-Trenaunay-Weber syndrome is a combination of venous and capillary malformations associated with soft tissue and/or bony hypertrophy, with or without lymphatic malformations. ${ }^{1}$ Typically, only one limb is involved, with the lower limbs representing $70 \%$ of cases. ${ }^{2}$ The aetiology of this syndrome is unknown, but some authors have suggested that it results from a mesodermal abnormality that occurs during fetal development. ${ }^{3}$ Bone hypertrophy usually results in limb length discrepancy. Treatment depends on the extent of the lesion, the severity of the symptoms and disability. The common surgical operations attempted are the excision, repair of venous malformation and debulking operations for tissue deformity with partial or complete amputations of the limbs. ${ }^{1}$

Acknowledgements We thank all doctors of MU III, Ward-4, Department of Medicine, Dhaka Medical College Hospital, Dhaka, Bangladesh.

Competing interests None.

Patient consent Obtained.

\section{REFERENCES}

1. Abdul-Rahman NR, Mohammad KF, Ibrahim S. Gigantism of the lower limb in Klippel-Trenaunay syndrome: anatomy of the lateral marginal vein. Singapore Med J 2009;50:e223-5.

2. Willis-Owen CA, Cobb JP. Total hip arthroplasty in Klippel-Trenaunay syndrome. Ann R Coll Surg Engl 2008;90:688.

3. Moodie D, Driscoll D, Salvatore D. Peripheral vascular disease in children. Klippel - Trenaunay syndrome. In: Young J, Olin J, Bartholomew J, eds Peripheral vascular diseases. 2nd edn. St Louis, Missouri, USA: Mosby Yearbook publishers, 1996:541-52.

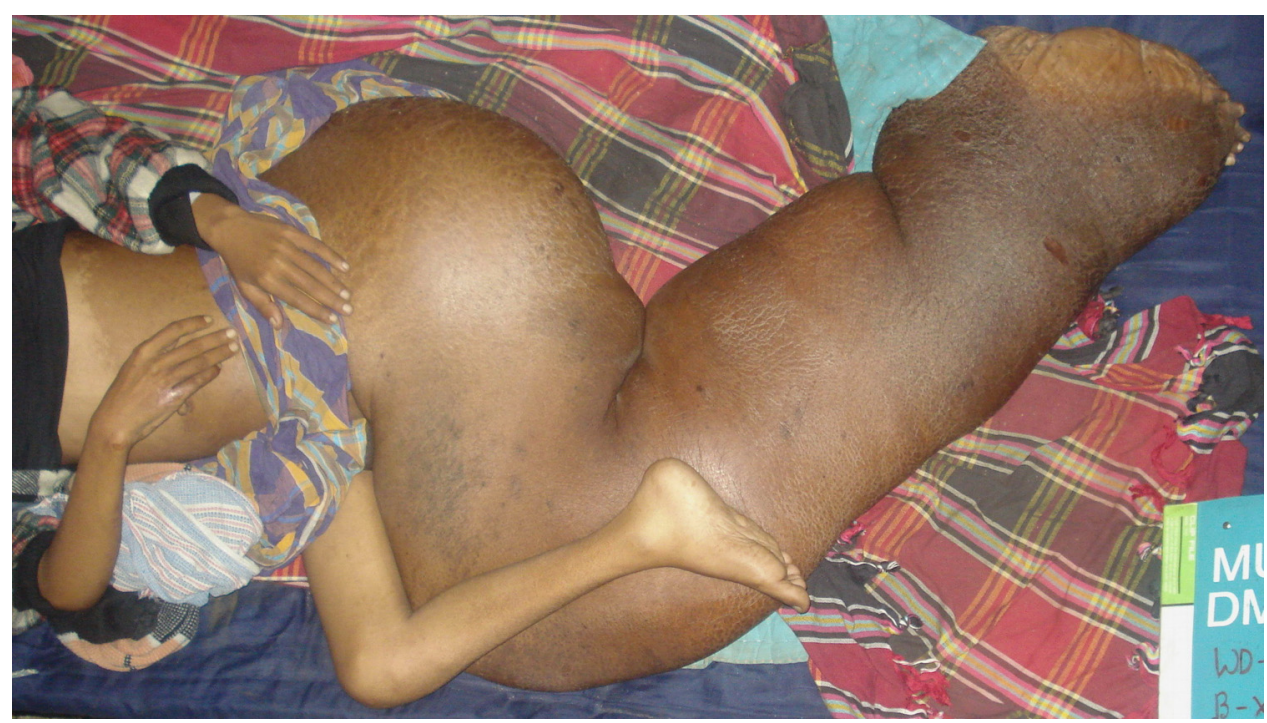

Figure 1 Giant left leg (5 feet 1 inches (approximately $155 \mathrm{~cm}$ ) in length and maximum diameter of 47 inches (approximately $119 \mathrm{~cm}$ )). 


\section{BMJ Case Reports}

This pdf has been created automatically from the final edited text and images.

Copyright 2010 BMJ Publishing Group. All rights reserved. For permission to reuse any of this content visit http://group.bmj.com/group/rights-licensing/permissions.

BMJ Case Report Fellows may re-use this article for personal use and teaching without any further permission.

Please cite this article as follows (you will need to access the article online to obtain the date of publication).

Siddiqui MR, Islam QT, Hossain A. Mystery of a giant leg. BMJ Case Reports 2010;10.1136/bcr.04.2010.2926, date of publication

Become a Fellow of BMJ Case Reports today and you can:

- Submit as many cases as you like

Enjoy fast sympathetic peer review and rapid publication of accepted articles

Access all the published articles

Re-use any of the published material for personal use and teaching without further permission

For information on Institutional Fellowships contact consortiasales@bmjgroup.com

Visit casereports.bmj.com for more articles like this and to become a Fellow 